Article

\title{
Age, Gender and Season Are Good Predictors of Vitamin D Status Independent of Body Mass Index in Office Workers in a Subtropical Region
}

\author{
Li-Kai Wang ${ }^{1,2} \mathbb{D}^{\circ}$, Kuo-Chuan Hung ${ }^{1,2}{ }^{(}$, Yao-Tsung Lin ${ }^{1,3}$, Ying-Jen Chang ${ }^{1,4}$, Zhi-Fu Wu ${ }^{1,5}{ }^{(}$, \\ Chung-Han Ho ${ }^{6}$ (D) and Jen-Yin Chen $1,7, *(\mathbb{D})$ \\ 1 Department of Anesthesiology, Chi Mei Medical Center, Tainan 71004, Taiwan; anesth@gmail.com (L.-K.W.); \\ ed102605@gmail.com (K.-C.H.); anekevin@hotmail.com (Y.-T.L.); 0201day@yahoo.com.tw (Y.-J.C.); \\ aneswu@gmail.com (Z.-F.W.) \\ Department of Health and Nutrition, Chia Nan University of Pharmacy and Science, Tainan 71710, Taiwan \\ Center of General Education, Chia Nan University of Pharmacy and Science, Tainan 71710, Taiwan \\ College of Health Sciences, Chang Jung Christian University, Tainan 71101, Taiwan \\ 5 Department of Anesthesiology, Tri-Service General Hospital and National Defense Medical Center, \\ Taipei 11490, Taiwan \\ 6 Department of Medical Research, Chi Mei Medical Center, Tainan 71004, Taiwan; ho.c.hank@gmail.com \\ 7 Department of the Senior Citizen Service Management, Chia Nan University of Pharmacy and Science, \\ Tainan 71710, Taiwan \\ * Correspondence: chenjenyin@gmail.com
}

Received: 27 July 2020; Accepted: 2 September 2020; Published: 5 September 2020

\begin{abstract}
This study aimed at determining the prevalence and predictors of hypovitaminosis D (serum 25-hydroxyvitamin $\mathrm{D}<30 \mathrm{ng} / \mathrm{mL}$ ) among office workers in a subtropical region from an electronic hospital database. Totally, 2880 office workers aged 26-65 years who received health examinations with vitamin $\mathrm{D}$ status and total calcium concentrations at a tertiary referral center were retrospectively reviewed. Subjects were divided into groups according to genders, age (i.e., 26-35, 36-45, 46-55, 56-65), body-mass index (BMI) (i.e., obese BMI $\geq 30$, overweight $25 \leq$ BMI $<30$, normal $20 \leq \mathrm{BMI}<25$, and underweight $\mathrm{BMI}<20$ ) and seasons (spring/winter vs. summer/autumn) for identifying the predictors of hypovitaminosis D. Corrected total calcium level $<8.4 \mathrm{mg} / \mathrm{dL}$ is considered as hypocalcemia. Multivariate logistic regression demonstrated that females (AOR 2.33, (95\% CI: 1.75, 3.09)), younger age $(4.32(2.98,6.24), 2.82(1.93,4.12), 1.50(1.03,2.17))$, and season (winter/spring) $(1.55(1.08,2.22))$ were predictors of hypovitaminosis $\mathrm{D}$, whereas BMI was not in this study. Despite higher incidence of hypocalcemia in office workers with hypovitaminosis D $(p<0.001)$, there was no association between vitamin D status and corrected total calcium levels. A high prevalence (61.9\%) of hypovitaminosis D among office workers in a subtropical region was found, highlighting the importance of this occupational health issue.
\end{abstract}

Keywords: occupational health; hypovitaminosis D; hypocalcemia; subtropical; season; gender; age

\section{Introduction}

Vitamin D is a secosteroid hormone regulating calcium homeostasis and bone metabolism. During the past decades, associations between vitamin D status and extra-skeletal health have been recognized. Vitamin D status is highly associated with the risks of autoimmune diseases [1], metabolic syndrome $[2,3]$ and neuropathic pain $[4,5]$. Serum 25-hydroxyvitamin $\mathrm{D}(25(\mathrm{OH}) \mathrm{D})$ is generally used as a marker of vitamin D status [6,7]. Based on the 2011 Endocrine Society Clinical Practice Guidelines, vitamin D status is defined as optimal (i.e., serum 25(OH)D concentration: $30-150 \mathrm{ng} / \mathrm{mL}$ ) 
and suboptimal (i.e., serum $25(\mathrm{OH}) \mathrm{D}$ concentration $<30 \mathrm{ng} / \mathrm{mL}$, hypovitaminosis D). Hypovitaminosis D includes insufficiency and deficiency defined as serum $25(\mathrm{OH}) \mathrm{D}$ concentrations $20-30 \mathrm{ng} / \mathrm{mL}$ and $<20 \mathrm{ng} / \mathrm{mL}$, respectively [8].

Vitamin D is called the "sunshine vitamin." During exposure to sunlight, ultraviolet-B (UVB) stimulates the conversion of 7-dehydrocholesterol (provitamin D) in the skin to pre-vitamin D which in turn isomerizes into vitamin D. Many factors have been shown to affect vitamin D status, including both environmental and personal characteristics/behaviors. Environmental factors, such as latitude [6] and season [9], determine whether there is sufficient UVB radiation to stimulate dermal vitamin D synthesis. Personal factors including gender [10-12], age [6,13], race [14,15], adiposity [15-17], physical activity [18], dietary habits [12,13] and occupation [19] can influence individual vitamin D status. Serum vitamin D status is a complex result of environmental and personal factors [6,20].

Indoor workers are consistently reported as being the occupational group most likely to suffer from hypovitaminosis D due to limited exposure to UVB radiation [19]. Subtropical regions are located between the tropic and temperate zones. Subtropical regions have plenty of sunshine all year round. Thus, people living in subtropical regions should not have hypovitaminosis D status. A hypovitaminosis D status was found in $44.1 \%$ of the adults aged 65 and older in a subtropical region and season was not a predictor of hypovitaminosis D in the study population [21]. Despite the common assumption that people living in sunny countries are at low risk of hypovitaminosis D, hypovitaminosis $\mathrm{D}$ was found to be highly prevalent among office workers in subtropical Australia [9]. Season was found to be more important than age and gender in determining serum $25(\mathrm{OH}) \mathrm{D}$ level for office workers in subtropical Australia [9]. Intriguingly, the association of age with serum 25(OH)D concentrations was found to vary during three study periods (i.e., 1988-1994, 2001-2004, 2007-2010) based on the data from the National Health and Nutrition Examination Survey in US [14,22]. While the serum 25(OH)D level decreased with advancing age during the first survey (i.e.,1988-1994), the level of the aged population became comparable to the younger age group during the second (i.e., 2001-2004) survey and even higher than their younger counterparts during the third survey (i.e., 2007-2010).The findings, therefore, highlighted the possible influence of other confounders rather than age per se on serum 25(OH)D levels. Furthermore, females often have a higher prevalence of hypovitaminosis D than that in males [10-12]. Anthropometrically, body mass index (BMI) has been found to be inversely associated with serum 25(OH)D levels [15-17]. Nevertheless, although Asians are known to have a lower BMI [23], the impact of BMI on serum 25(OH)D levels in Asian office workers has not been addressed.

Taking into account the scarcity of research regarding serum vitamin D status among indoor office workers in subtropical regions [9] and the fact that serum vitamin D status is the result of complex interactions among various environmental and personal factors $[6,20]$, the present study aimed at investigating the prevalence of hypovitaminosis D among indoor office workers in subtropical Taiwan and identifying factors that independently determine $25(\mathrm{OH}) \mathrm{D}$ levels of this population. Determination of serum calcium levels is often available and widely included as a routine laboratory test, but determination of serum $25(\mathrm{OH}) \mathrm{D}$ levels may be not. It raised a question whether hypovitaminosis $\mathrm{D}$ could be suspected based on calcium levels. We therefore assessed the association between corrected total serum calcium levels and 25(OH)D concentrations in the study subjects.

\section{Methods}

\subsection{Study Population}

Self-administered questionnaires were used to collect data including job types (office workers, ... and others) on all adults who received health examinations at Chi Mei Medical Center, a 1200-bed tertiary referral center in southern Taiwan with 22.5-22.9 $\mathrm{N}$ latitude. Colonoscopy, serum 25(OH)D and total calcium concentrations are grouped as one option among the health examination survey at Chi Mei Medical Center. Health examination data at Chi Mei Medical Center between 1 December 2016 and 31 November 2018 stored in the electronic database of the institute were retrospectively reviewed 
and analyzed. Inclusion criteria for the present study were (1) subjects aged $26-65$ years (26 is the average age of Taiwanese adults with a stable occupation; 65 is the official retirement age); (2) office workers; and (3) those with available data of serum 25(OH)D and total calcium/phosphate/creatinine examinations during the study period. Exclusion criteria were: (1) individuals who had diagnostic codes of human immunodeficiency virus infection [International Classification of Diseases, Ninth Revision (ICD-9) 042, 043, 044], organ transplants (ICD-9 3751, 1160, 1164, 1169, 5059, 5280, 5283, 5569, 3350-3352), liver disease (ICD-9 571) and/or chronic renal failure (ICD-9 585)on dialysis, which are potential confounders of hypovitaminosis D [24-26] as well as (2) individuals whose medical records showed no evidence of serum $25(\mathrm{OH}) \mathrm{D}$ and total calcium examinations during the study period. The study was conducted in accordance with the Declaration of Helsinki.

This retrospective study was approved by the Institutional Review Board of the Chi Mei Medical Center, Tainan, Taiwan (IRB-10711-001).

\subsection{Study Parameters and Definitions}

Because the prevalence of vitamin D deficiency has been found to be statistically associated with age, gender, and seasons [27], the impacts of gender, age, season, and BMI on serum 25(OH)D concentrations in the study population were studied. To investigate the influence of age on serum 25(OH)D levels, all eligible subjects were divided into four age groups: $26-35,36-45,46-55$, and 56-65. The seasons were categorized into the two seasons with shorter daylight (i.e., Winter and Spring) and the other two with longer daylight (i.e., Summer and Autumn) to assess the association between season and serum $25(\mathrm{OH}) \mathrm{D}$ levels. BMI was calculated as the weight in kilograms divided by the square of height in meters $\left(\mathrm{kg} / \mathrm{m}^{2}\right)$. All subjects were divided into those who were obese (i.e., BMI $\geq 30$ ), overweight $(25 \leq \mathrm{BMI}<30)$, normal $(20 \leq \mathrm{BMI}<25)$, and underweight $(\mathrm{BMI}<20)$ [15] to evaluate the effect of BMI on serum 25(OH)D concentrations. Corrected total serum calcium concentrations was calculated by measured total calcium $+(0.8 \times(4.0-($ albumin $))$. A serum calcium $<8.4 \mathrm{mg} / \mathrm{dL}$ with a normal serum albumin ( 3.4 to $5.4 \mathrm{~g} / \mathrm{dL}$ ) is defined as hypocalcemia [28]. Hypercalcemia is considered if the corrected total serum calcium level is $>10.4 \mathrm{mg} / \mathrm{dL}$ [29]. Furthermore, phosphate can bind calcium avidly to cause hypocalcemia during acute hyperphosphatemia. In chronic renal failure, hypocalcemia is common because of reduced renal synthesis of 1,25-dihydroxyvitamin D and an increase in fibroblast growth factor 23 [30]. Thus, serum phosphate levels and creatinine-based estimated glomerular filtration rate (eGFR) were also investigated.

\subsection{Subject Selection}

The study subjects were selected using block randomization approach for controlling the potential confounding factors. Because at least 30 subjects are needed for establishing a relationship in correlational research [31], a total of 60 subjects with a female to male ratio of 1:1 and at least one subject in each year age to achieve age equality for each of the four age groups were randomly selected and allocated to the 12 months of a year (i.e., from January to December) during the two-year study period so that there were 720 individuals (i.e., 360 females and 360 males) in each age group and in each season. Based on an estimated total number of 20 thousand subjects undergoing health examination during the study period, a sample size of about $10 \%$ (i.e., two thousand) would fit the recommendation for a descriptive research [31].

\subsection{Blood Collection and Determination of Serum 25(OH)D Levels}

The serum sample, which was acquired from a fasting blood sample of each subject after centrifugation and stored at a temperature of $-70^{\circ} \mathrm{C}$, was subject to serum $25(\mathrm{OH}) \mathrm{D}$ quantification using automated Chemiluminescent Microparticle Immuno Assay [5,32] (ARCHITECTi2000 (Abbott, Chicago, IL, USA) as our previous study [5]. 


\subsection{Blood Collection and Determination of Total Serum Calcium, Phosphate, Creatinine and Albumin}

The determination of total serum calcium concentrations was based on calcium ions (Ca2+) reacting with Arsenazo III (ARCHITECT calcium reagent) to generate a purple colored complex with a sensitive absorbance peak at $600-660 \mathrm{~nm}$. The absorbance of the Ca-Arsenazo III complex was measured bichromatically at 660/700 nm (ABBOTT Architect c8000/c16000). The absorbance of the Ca-Arsenazo III complex is directly proportional to the calcium concentration in the sample. In this method, magnesium does not significantly interfere with calcium determination. However, very small amounts of copper ions may interfere with calcium determination. This problem was overcome by adding $15 \mathrm{mmol} / \mathrm{L}$ thiourea to the calcium reagent [33]. Serum calcium is stable for up to 7 days at room temperature $\left(15-25^{\circ} \mathrm{C}\right)$ [33]. Using UV-spectrophotometry, phosphate may be determined in serum as the phosphomolybdic acid complex, the absorbance of which was measured bichromatically at 700/880 nm (ABBOTT Architect c8000/c16000). The absorbance of the phosphomolybdic acid complex is directly proportional to the phosphate concentration in the sample [34]. Serum creatinine was measured by a Jaffe method, alkaline picrate kinetic (ABBOTT Architect c8000/c16000).

Serum albumin was measured with dye-binding assay using bromocresol green (BCG) method. BCG binds albumin to form albumin-BCG complex (a colored compound). Its absorbance, measured at $630 \mathrm{~nm}(620-640)$, is directly proportional to the albumin concentration in the sample (ABBOTT Architect c8000/c16000) [35].

All of the aforementioned blood examinations were performed every weekday.

\subsection{Statistical Analysis}

Data processing and statistical analysis were performed using SAS statistical software (Version 9.4; SAS Institute, Cary, NC, USA). The difference of continuous data between groups was conducted by Student $t$ test. Chi-square test or Fisher exact test was used to determine the significance of differences in categorical variables among groups. Univariate logistic regression analysis was used to identify predictors of hypovitaminosis D. Confounding factors including gender, age groups, and season were adjusted to evaluate the odds ratio in different models. Variables that were associated with hypovitaminosis $\mathrm{D}(p<0.10)$ on univariate analyses were entered into a multivariate logistic regression model. Independent predictors of hypovitaminosis $\mathrm{D}(<30 \mathrm{ng} / \mathrm{mL})$ were presented as adjusted odds ratios (AOR) and $95 \%$ confidence intervals (CI). A two-sided $p$ value $<0.05$ was deemed significant.

Corrected total serum calcium concentrations was calculated by measured total calcium $+(0.8 \times(4.0-($ albumin $)))$. According to corrected total serum calcium concentrations, subjects were dichotomized into two groups: hypocalcemia $(<8.4 \mathrm{mg} / \mathrm{dL})$ and normal levels $(8.4 \sim 10.4 \mathrm{mg} / \mathrm{dL})$. For identifying the sensitivity and specificity in predicting $25(\mathrm{OH}) \mathrm{D}$, a receiver operating characteristic (ROC) curve was plotted. The area under the ROC curve (AUC) was used to measure the diagnostic ability of hypovitaminosis D in four models. Model 1: The ROC curve for hypocalcemia to predict the incidence of hypovitaminosis D. Model 2: Adjusted for age, gender and season. Model 3: Adjusted for age, gender, season and phosphorus levels. Model 4: Adjusted for age, gender, season, phosphorus levels and eGFR.

\section{Results}

\subsection{Demographic and Anthropometric Characteristics of the Study Population}

Of a total of 20,023 eligible subjects, 2880 indoor office workers (14.4\%) were randomly selected from the electronic medical database. The demographic and anthropometric characteristics of the study population are shown in Table 1. Hypovitaminosis D was prevalent, with a female prominence in gender, all age groups and seasons (all $p<0.001)$. High prevalence of hyperphosphatemia $(>6.5 \mathrm{mg} / \mathrm{dl})$ was noted in the study population. 
Table 1. Demographic characteristics of indoor workers in subtropical Taiwan.

\begin{tabular}{|c|c|c|c|c|}
\hline & Total $(n=2880)$ & Female $(n=1440)$ & Male $(n=1440)$ & $p$ \\
\hline Age, mean (SD), years & $46(11)$ & $46(11)$ & $46(11)$ & 1.0 \\
\hline BMI, mean (SD) & $24(4)$ & $22(4)$ & $25(4)$ & 0.75 \\
\hline \multicolumn{5}{|l|}{ Vitamin D status, $n(\%)$} \\
\hline Optimal $(\geq 30 \mathrm{ng} / \mathrm{mL})$ & $1098(38.1)$ & $405(28.1)$ & $693(48.1)$ & $<0.001$ \\
\hline Hypovitaminosis $\mathrm{D}(<30 \mathrm{ng} / \mathrm{mL})$ & $1782(61.9)$ & $1035(71.9)$ & 747 (51.9) & \\
\hline $25(\mathrm{OH}) \mathrm{D}$, mean $(\mathrm{SD}), \mathrm{ng} / \mathrm{mL}$ & $29(9)$ & $26(8)$ & $31(10)$ & $<0.001$ \\
\hline \multicolumn{5}{|l|}{$25(\mathrm{OH}) \mathrm{D}$ in age groups, mean (SD), $\mathrm{ng} / \mathrm{mL}, n$} \\
\hline $26-35$ years & $26(7), 720$ & $23(7), 360$ & $28(7), 360$ & $<0.001$ \\
\hline $36-45$ years & $27(8), 720$ & $25(7), 360$ & $29(9), 360$ & $<0.001$ \\
\hline $46-55$ years & $30(9), 720$ & $28(8), 360$ & $31(9), 360$ & $<0.001$ \\
\hline $56-65$ years & $33(10), 720$ & $30(8), 360$ & $35(12), 360$ & $<0.001$ \\
\hline \multicolumn{5}{|l|}{$25(\mathrm{OH}) \mathrm{D}$ in seasons, mean (SD), $\mathrm{ng} / \mathrm{mL}, n$} \\
\hline Shorter daylight (Winter/Spring) & $28(9), 1440$ & $26(7), 720$ & $30(10), 720$ & $<0.001$ \\
\hline Longer daylight (Summer/Autumn) & $30(9), 1440$ & $27(7), 720$ & $32(10), 720$ & $<0.001$ \\
\hline \multicolumn{5}{|l|}{$25(\mathrm{OH}) \mathrm{D}$ in $\mathrm{BMI}$ groups, mean (SD) $\mathrm{ng} / \mathrm{mL} n$} \\
\hline Obese $(\geq 30.0)$ & $28(9), 203$ & $27(8), 57$ & $28(9), 146$ & 0.63 \\
\hline Overweight $(25 \leq \mathrm{BMI}<30)$ & $29(9), 741$ & $28(8), 239$ & $30(9), 502$ & 0.01 \\
\hline Normal $(20 \leq \mathrm{BMI}<25)$ & $29(10), 1431$ & $26(8), 741$ & $31(10), 690$ & $<0.001$ \\
\hline Under weight $(<20.0)$ & $27(8), 505$ & $26(8), 403$ & $32(10), 102$ & $<0.001$ \\
\hline $\begin{array}{l}\text { Corrected total serum calcium concentration, } \\
\text { mean (SD), } \mathrm{mg} / \mathrm{ml}\end{array}$ & $8(1)$ & $8(0)$ & $8(1)$ & 0.33 \\
\hline Serumphosphate concentration, mg/ml & $7(2)$ & $7(2)$ & $7(2)$ & 0.19 \\
\hline eGFR & $83(15)$ & $85(14)$ & $82(15)$ & 0.65 \\
\hline
\end{tabular}

n: number.

\subsection{Distribution of Serum Vitamin D among Indoor Office Workers}

Hypovitaminosis D (deficiency/insufficiency) was found in up to $61.9 \%$ (1782) of the study population, with deficiency $(<20 \mathrm{ng} / \mathrm{mL})$ and insufficiency $(20-30 \mathrm{ng} / \mathrm{mL})$ being noted in $14.2 \%(408)$ and $47.7 \%$ (1374) of subjects, respectively (Figure 1a). Analysis of the distribution of serum $25(\mathrm{OH}) \mathrm{D}$ concentrations demonstrated a dominance of vitamin D insufficiency in both genders ( $52.4 \%$ females and $43.0 \%$ males) (Figure $1 \mathrm{~b}$ ). In addition, hypovitaminosis D was significantly more common in female than in male indoor workers $(71.9 \%$ vs. $51.9 \%$, respectively, $p<0.001)$. None of the subjects showed vitamin D toxicity (i.e., serum $25(\mathrm{OH}) \mathrm{D}>150 \mathrm{ng} / \mathrm{mL}$ ).

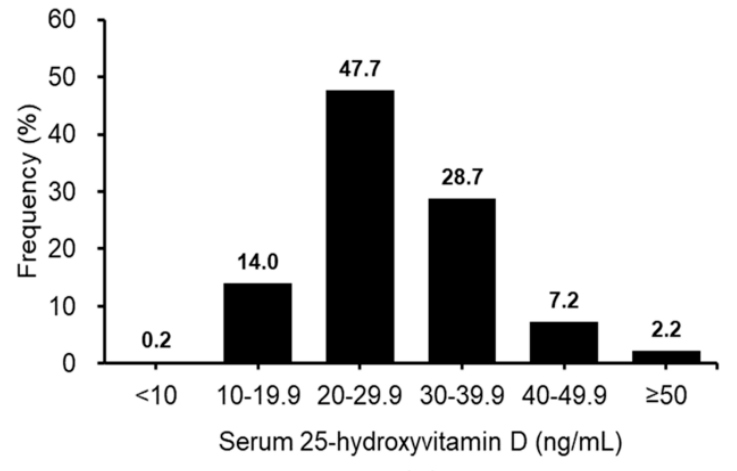

(a)

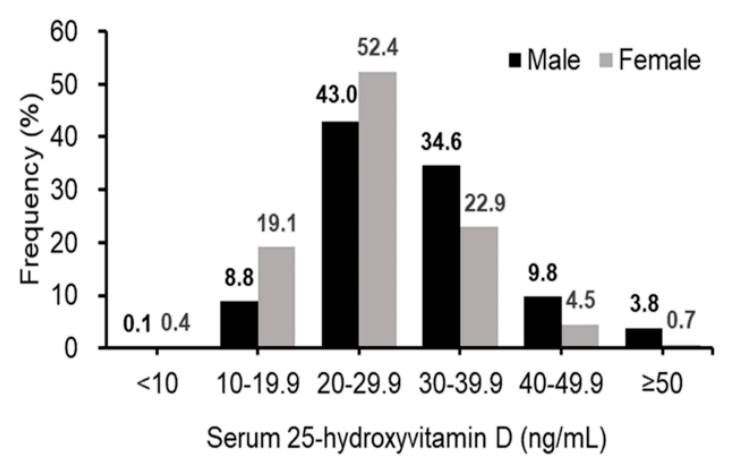

(b)

Figure 1. Distribution of serum 25(OH)D concentrations among indoor workers. (a) Age-specific distributions of serum 25(OH)D concentrations in the total study population. (b) Age-specific distributions of serum 25(OH)D concentrations in males and females separately.

\subsection{Associations of Risks of Hypovitaminosis D with Gender, Age, Season, and Body-Mass Index}

The correlations between the risks of hypovitaminosis $\mathrm{D}$ and demographic/environmental factors (i.e., gender, age, season, and body-mass index) of 2880 indoor workers are presented in Table 2. The mean 25(OH)D concentration of the indoor workers was $28.61 \pm 8.92 \mathrm{ng} / \mathrm{mL}$. Univariate logistic regression revealed a female predominance of hypovitaminosis D (crude OR 2.37, 95\% CI 2.03, 2.77). 
There was a significant trend of increasing incidences of hypovitaminosis D with decreasing ages with the incidence lowest in the elderly age group (56-65) and highest in the youngest age group (26-35) $(p<0.001)$ (Table 2). With reference to that of the 56-65 age group, the crude OR of hypovitaminosis D for the 26-35, 36-45, and 46-55 age groups were 3.65 (95\% CI 2.91, 4.56), 2.81 (95\% CI 2.26, 3.49), and $1.52(95 \%$ CI 1.23, 1.87), respectively. There was also a significant seasonal variation in hypovitaminosis $\mathrm{D}$ with an increased risk in winter/spring compared to that in summer/autumn (crude OR 1.43, 95\% CI $1.23,1.67)$. On the other hand, there were no significant associations between BMI and hypovitaminosis D. Multivariate logistic regression analysis identified age, gender and season significant predictors of hypovitaminosis D independent of BMI in indoor office workers in subtropical Taiwan.

Table 2. Characteristics of all indoor office workers and indoor workers with hypovitaminosis D or optimal vitamin D levels.

\begin{tabular}{|c|c|c|c|c|}
\hline Vitamin D Status & $\begin{array}{c}\text { Hypovitaminosis D } \\
(<30 \mathrm{ng} / \mathrm{mL}), \\
n=1782(61.9 \%), n(\%)\end{array}$ & $\begin{array}{l}\text { Optimal }(\geq 30 \mathrm{ng} / \mathrm{mL}), \\
n=1098(38.1 \%), n(\%)\end{array}$ & $\begin{array}{l}\text { Crude OR } \\
(95 \% \mathrm{CI})\end{array}$ & $\begin{array}{l}\text { Adjusted OR } \\
\quad(95 \% \mathrm{CI})\end{array}$ \\
\hline \multicolumn{5}{|l|}{ Gender } \\
\hline Female $(n=1440)$ & 1035 (71.9) & $405(28.1)$ & $2.37(2.03,2.77)$ & $2.33(1.75,3.09)$ * \\
\hline Male $(n=1440)$ & 747 (52.7) & $693(47.3)$ & 1.0 & 1.0 \\
\hline \multicolumn{5}{|l|}{ Age group, years } \\
\hline $26-35(n=720)$ & $543(75.4)$ & $177(24.6)$ & $3.65(2.91,4.56)$ & $4.32(2.98,6.24)$ * \\
\hline $36-45(n=720)$ & $506(70.3)$ & $214(29.7)$ & $2.81(2.26,3.49)$ & $2.82(1.93,4.12)$ * \\
\hline $46-55(n=720)$ & $404(56.1)$ & $316(43.9)$ & $1.52(1.23,1.87)$ & $1.50(1.03,2.17)$ * \\
\hline $56-65(n=720)$ & $329(45.7)$ & $391(54.3)$ & 1.0 & 1.0 \\
\hline \multicolumn{5}{|l|}{ Season } \\
\hline $\begin{array}{c}\text { (Winter/Spring) } \\
(n=1440)\end{array}$ & $952(66.1)$ & $488(33.9)$ & $1.43(1.23,1.67)$ & $1.55(1.08,2.22)$ * \\
\hline $\begin{array}{l}\text { (Summer/Autumn) } \\
(n=1440)\end{array}$ & $830(57.6)$ & $610(42.4)$ & 1.0 & 1.0 \\
\hline \multicolumn{5}{|l|}{ BMI $\left(\mathrm{kg} / \mathrm{m}^{2}\right)$} \\
\hline Obese $(\geq 30.0)$ & $133(65.5)$ & $70(34.5)$ & $1.17(0.86,1.59)$ & \\
\hline $\begin{array}{c}\text { Overweight } \\
(25 \leq \mathrm{BMI}<30)\end{array}$ & $427(57.6)$ & $314(42.4)$ & $0.84(0.70,1.00)$ & \\
\hline Normal $(20 \leq \mathrm{BMI}<25)$ & $886(61.9)$ & $545(38.1)$ & 1.0 & \\
\hline Under weight $(<20.0)$ & $336(66.5)$ & $169(33.5)$ & $1.22(0.99,1.51)$ & \\
\hline
\end{tabular}

\subsection{Subgroup Analysis by Genders for Predictors of Hypovitaminosis D}

According to subgroup analysis by gender, multivariate logistic regression revealed that only the 36-45 and 26-35 age groups remained significant predictors of hypovitaminosis D with reference to the 56-65 age group in females (AOR 3.22; 4.05) and males (AOR 2.30; 4.73). Interestingly, season did not independently predict hypovitaminosis $\mathrm{D}$ in females by multivariate logistic analysis (Table 3 ). In males, there was a significant increase in the risk of hypovitaminosis D in winter/spring compared to that in summer/autumn by multivariate logistic analysis (AOR 1.99, 95\% CI 1.40, 2.83) (Table 4). No significant associations between BMI and serum $25(\mathrm{OH}) \mathrm{D}$ were found in both genders.

\subsection{Associations between Hypovitaminosis D and Corrected Total Serum Calcium Concentrations}

Only one subject had a low albumin level $(2.8 \mathrm{~g} / \mathrm{dL})$. Corrected total calcium concentrations of the present study population ranged from 7.06 to $10.2 \mathrm{mg} / \mathrm{mL}$ with none having hypercalcemia. Subjects with hypocalcemia had higher incidences of hypovitaminosis $\mathrm{D}(65.8 \%)$ and lower mean concentrations $(8.39 \mathrm{mg} / \mathrm{mL})$ of corrected total serum calcium levels compared to those $(58.1 \%, 8.47 \mathrm{mg} / \mathrm{mL})$ in subjects with an optimal vitamin D status (both $p<0.001$ ) (Table 5). However, $47.5 \%(847 / 1782)$ subjects with hypovitaminosis D had normal corrected total serum calcium concentrations; conversely, $44.0 \%$ subjects (483/1098) with optimal vitamin D status had hypocalcemia. The ROC curves for hypocalcemia to predict the incidence of hypovitaminosis D were plotted in model 1 . The AUC was 0.542 indicating no 
discrimination. In addition, the adjusted AUC was approximately 0.57 in Model 2, 3 and 4 indicating no discrimination (Figure 2).

Table 3. Subgroup analysis of adjusted OR and 95\% CI for the risk of hypovitaminosis D in females.

\begin{tabular}{|c|c|c|c|c|}
\hline & Females & $(n=1440)$ & & \\
\hline Vitamin D Status & $\begin{array}{l}\text { Hypovitaminosis } \\
\mathrm{D}, n=1035, \mathrm{n}(\%)\end{array}$ & $\begin{array}{c}\text { Optimal, } \\
n=405, n(\%)\end{array}$ & $\begin{array}{c}\text { Crude OR } \\
(95 \% \mathrm{CI})\end{array}$ & $\begin{array}{l}\text { Adjusted OR } \\
\text { (95\% CI) }\end{array}$ \\
\hline \multicolumn{5}{|l|}{ Age group, years } \\
\hline $26-35(n=360)$ & $308(86.1)$ & $52(13.9)$ & $4.74(3.31,6.79)$ & $4.05 *(2.35,6.98)$ \\
\hline $36-45(n=360)$ & $292(81.1)$ & $68(18.9)$ & $3.44(2.46,4.81)$ & $3.22 *(1.81,5.71)$ \\
\hline $46-55(n=360)$ & $235(65.3)$ & $125(34.7)$ & $1.50(1.11,2.03)$ & $1.67(1.00,2.80)$ \\
\hline $56-65(n=360)$ & $200(55.6)$ & $160(44.4)$ & 1.0 & 1.0 \\
\hline \multicolumn{5}{|l|}{ Season } \\
\hline (Winter/Spring) $(n=720)$ & $538(74.7)$ & $182(25.3)$ & $1.33(1.05,1.67)$ & $1.12(0.78,1.62)$ \\
\hline (Summer/Autumn) $(n=720)$ & $497(69.0)$ & $223(31.0)$ & 1.0 & 1.0 \\
\hline \multicolumn{5}{|l|}{ BMI $\left(\mathrm{kg} / \mathrm{m}^{2}\right), n(\%)$} \\
\hline Obese $(\geq 30.0)$ & $39(68.4)$ & $18(31.6)$ & $0.84(0.47,1.50)$ & \\
\hline Overweight $(25 \leq \mathrm{BMI}<30)$ & $169(70.7)$ & $70(29.3)$ & $0.94(0.68,1.29)$ & \\
\hline Normal $(20 \leq \mathrm{BMI}<25)$ & $534(72.1)$ & $207(27.9)$ & 1.0 & \\
\hline Under weight $(<20.0)$ & $293(72.7)$ & $110(27.3)$ & $1.0(0.79,1.35)$ & \\
\hline
\end{tabular}

Table 4. Subgroup analysis of adjusted OR and 95\% CI for the risk of hypovitaminosis D in males.

\begin{tabular}{|c|c|c|c|c|}
\hline & Males & $(n=1440)$ & & \\
\hline Vitamin D Status & $\begin{array}{l}\text { Hypovitaminosis D, } \\
\quad n=747, n(\%)\end{array}$ & $\begin{array}{c}\text { Optimal, } \\
n=693, n(\%)\end{array}$ & $\begin{array}{l}\text { Crude OR } \\
(95 \% \text { CI })\end{array}$ & $\begin{array}{l}\text { Adjusted OR } \\
(95 \% \text { CI })\end{array}$ \\
\hline \multicolumn{5}{|l|}{ Age group, years } \\
\hline $26-35(n=360)$ & $235(65.8)$ & $125(34.2)$ & $3.37(2.48,4.57)$ & $4.73 *(2.76,8.09)$ \\
\hline $36-45(n=360)$ & $214(60.6)$ & $146(39.4)$ & $2.62(1.94,3.55)$ & $2.30 *(1.34,3.92)$ \\
\hline $46-55(n=360)$ & $169(47.5)$ & $191(52.5)$ & $1.58(1.18,2.14)$ & $1.22(0.70,2.13)$ \\
\hline $56-65(n=360)$ & $129(36.9)$ & $231(63.1)$ & 1.0 & 1.0 \\
\hline \multicolumn{5}{|l|}{ Season } \\
\hline (Winter/Spring) $(n=720)$ & $414(57.5)$ & $306(42.5)$ & $1.57(1.28,1.94)$ & $1.99 *(1.40,2.83)$ \\
\hline (Summer/Autumn) $(n=720)$ & $333(46.2)$ & $387(53.8)$ & 1.0 & 1.0 \\
\hline \multicolumn{5}{|l|}{ BMI $\left(\mathrm{kg} / \mathrm{m}^{2}\right), n(\%)$} \\
\hline Obese $(\geq 30.0)$ & $94(64.4)$ & $52(35.6)$ & $1.74(1.20,2.51)$ & $1.27(0.89,1.94)$ \\
\hline Overweight (2530) & $258(51.4)$ & $244(48.6)$ & $1.02(0.81,1.28)$ & $1.06(0.85,1.23)$ \\
\hline Normal $(20 \leq \mathrm{BMI}<25)$ & $352(51.0)$ & $338(49.0)$ & 1.0 & 1.0 \\
\hline Under weight $(<20.0)$ & $43(42.2)$ & $59(57.8)$ & $0.70(0.46,1.07)$ & $0.78(0.57,1.10)$ \\
\hline
\end{tabular}

OR: odds ratio; CI: confidence intervals. Multivariate logistic regression models adjusted for age, season and BMI. * $p<0.05$.

Table 5. Distribution of hypovitaminosis D and optimal vitamin D among indoor workers with hypocalcemia and normal calcium levels.

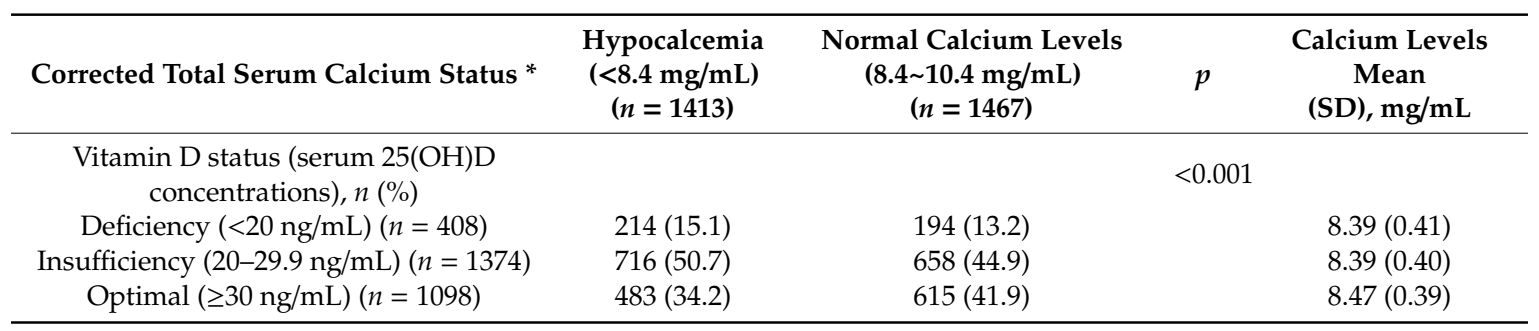

$n$ : number. ${ }^{*}$ None had hypercalcemia. Corrected total serum calcium concentrations was calculated by measured total calcium $+(0.8 \times(4.0-($ albumin $)))$. 


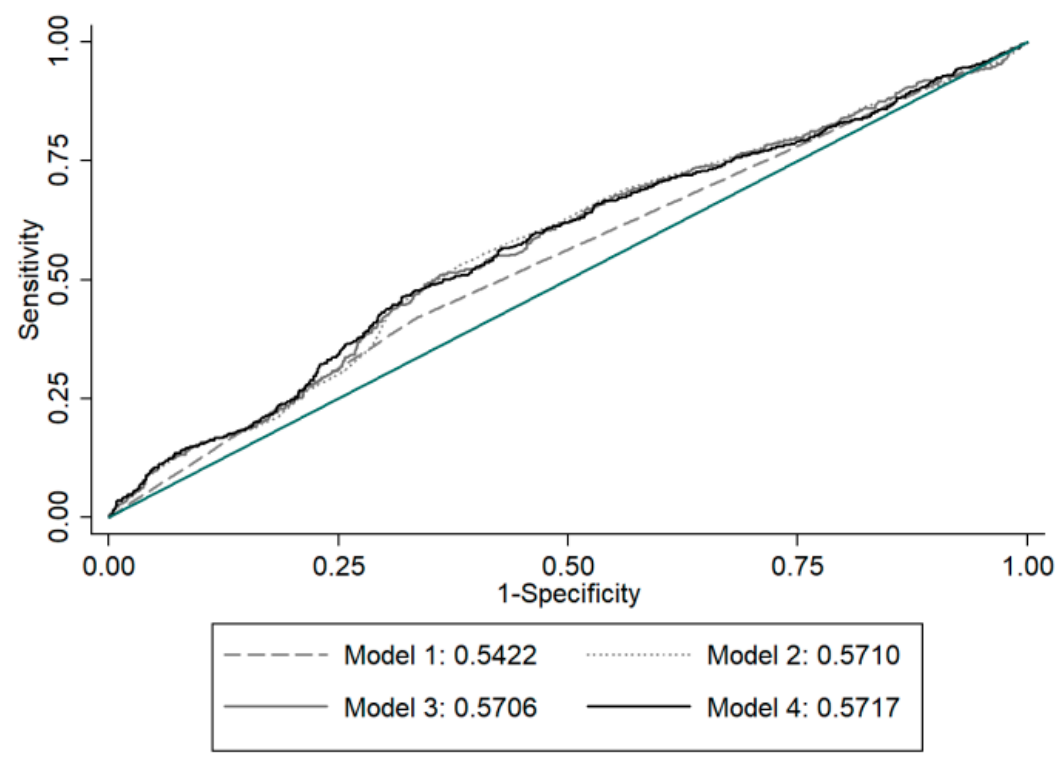

Figure 2. The receiver operating characteristic (ROC) curves for hypocalcemia to predict the incidence of hypovitaminosis D in Model 1. Adjusted for age, gender and season in Model 2. Adjusted for age, gender, season and phosphorus in Model 3. Adjusted for age, gender, season, phosphorus and estimated glomerular filtration rate (eGFR) in Model 4. The diagonal green line represents the line of no-discrimination.

\section{Discussion}

The current study demonstrated a high prevalence (61.9\%) of hypovitaminosis D (deficiency/insufficiency) with $14.2 \%$ deficiency and $47.7 \%$ insufficiency among indoor office workers in subtropical Taiwan. Study on the distribution of serum $25(\mathrm{OH}) \mathrm{D}$ concentrations revealed the highest proportion of vitamin $\mathrm{D}$ insufficiency (i.e., $20-30 \mathrm{ng} / \mathrm{dL}$ ) in both genders (52.4\% females and $43.0 \%$ males) of indoor workers. The findings were consistent with those of a previous report [9] that demonstrated a high prevalence of hypovitaminosis D in indoor workers even in subtropical sunny Australia when skin exposure to UVB sunlight was limited by the nature of occupation.

Multivariate logistic regression showed that age, gender and season were significant predictors of hypovitaminosis D in indoor workers independent of BMI in subtropical Taiwan. Interestingly, hypovitaminosis D was more prevalent in the younger groups in the current study. Subgroup analysis by gender in multivariate logistic regression showed that a younger age (26-45 years old) independently predicted hypovitaminosis $\mathrm{D}$ in both genders of indoor workers in Taiwan. The finding is consistent with that in recent reports from Korea [36], Thailand [37] and US [22] demonstrating a predisposition to hypovitaminosis D among the younger generation [38]. Although an advanced age is generally associated with an increased risk of hypovitaminosis $\mathrm{D}$ attributable to two factors: the decreased efficacy of vitamin D synthesis through UVB-irradiation with aging [39] and less physical activity in the elderly [18], the findings of the present study and those of others [22,36-38] appeared to defy such a belief. Some possible explanations include the inclination of the younger generation to stay indoors due to the exponential increase in the utilization of computer technologies both at work and at home [14,40], the use of sunscreen among young people because of cosmetic reasons [38], and a low prevalence of vitamin D intake from vitamin D supplements $(<5 \%)$ among younger Taiwan people compared to that in the aged population (20\%) [13]. The finding of the current study highlighted the widespread hypovitaminosis D problem in the young generation as an urgent health issue that needs to be addressed. Moreover, there is a need to develop and promote strategies to maintain adequate vitamin $\mathrm{D}$ status in the young generation.

The incidence of hypovitaminosis $\mathrm{D}$ was higher in females than that in males in all age groups. Previous studies have demonstrated a lower vitamin D status in Asian women than that in Asian 
men [10-12], whereas there was no gender difference in serum 25(OH)D in the United States [14,22]. Possible explanations include the general preference of indoor activities among Asian women to avoid sunlight exposure and skin-tanning [11,20,41]. Previous nutrition and health surveys in Taiwan demonstrated a lower mean daily dietary intake of vitamin D in females aged 19-64 in comparison with that in their male counterparts despite a higher consumption of vitamin D supplements in females [13]. Overall, the total vitamin D intake (i.e., food and supplements) in females was lower than that in males [13]. Serum vitamin D status is the result of a complex interaction involving multiple factors including sunlight availability, actual exposure, dietary vitamin D intake and the use of supplements [6,20]. Vitamin D supplementation can be considered to be an alternative to prevent hypovitaminosis D for females. Government should encourage research programs on the impact of hypovitaminosis $\mathrm{D}$ on females and individuals with minimal sun exposure.

The present study showed that season (winter/spring) was an independent predictor of hypovitaminosis D for office workers in subtropical Taiwan. The finding is similar to that of a previous study on office workers in subtropical Australia [9]. Interestingly, season was found to be more important than age and gender in determining serum $25(\mathrm{OH}) \mathrm{D}$ level for office workers in subtropical Australia [9]. However, age and gender were found to be more important than season in determining serum $25(\mathrm{OH}) \mathrm{D}$ level for office workers in subtropical Taiwan. In particular, subgroup analysis by gender in the current study revealed a significant increase in the risk of hypovitaminosis $\mathrm{D}$ during winter/spring in males only but not in females. The lack of seasonal difference in serum $25(\mathrm{OH}) \mathrm{D}$ levels and the significantly higher incidence of hypovitaminosis D compared with that in males regardless of season among the female population may be partly explained by the fact that Taiwanese females, like those in Hong Kong, Japanese, and Korea, tend to avoid sun exposure by using sunscreen and parasols due to cosmetic concern based on the cultural aesthetic concept [11,20,41]. A longitudinal one-year study among indoor workers also revealed that the monthly change in $25(\mathrm{OH}) \mathrm{D}$ in males was more significant than that in females in Japan [42]. Nevertheless, the relative impact of this behavioral factor on $25(\mathrm{OH}) \mathrm{D}$ status remains to be elucidated.

Previous studies have demonstrated an inverse correlation between BMI and serum 25(OH)D concentrations in adults, in particular those who are "overweight" (BMI $25 \leq$ BMI < 30) or "obese" (BMI $\geq 30)[16,17]$. However, compared with those with BMI within the normal range, there was no statistical association between BMI and the risk of hypovitaminosis D in the current study. Consistently, a previous study also showed no significant correlation between the vitamin D status and BMI in underweight individuals and those with normal body weight [16]. In addition, a high prevalence of vitamin D deficiency was found in those with a BMI $\geq 40$ (i.e., $32 \%$ in women and $46 \%$ in men [16]. Therefore, the lack of correlation between BMI and the risk of hypovitaminosis D in the present study may be due to the overall low BMI among indoor workers in subtropical Taiwan (i.e., 14.4 to 36.1 in females, 15.8 to 39.7 in males) with only $7.0 \%$ and $25.7 \%$ of the subjects being obese and overweight, respectively. Besides, none of them had a BMI $\geq 40.0$ (Data not shown). Nevertheless, a previous large-scale study on Taiwanese adults comparing the characteristics of those with vitamin $\mathrm{D}$ deficiency and those without showed that the former had a significantly lower mean BMI (23.96 \pm 3.99$)$ than that of the latter $(24.65 \pm 3.72)$ [26]. However, that study did not focus on indoor workers and no multivariate regression analysis was performed to further elucidate the predictive value of BMI for vitamin D deficiency. When both genders were analyzed separately, neither showed significant association between the risk of hypovitaminosis D and BMI. Possible reasons could be malnutrition resulting from an attempt to maintain an ideal lean body mass in Taiwanese females [41]. Possibly, males who were overweight but not obese were not physically inactive because physical activity was shown to effectively increase vitamin D concentrations [18]. Therefore, overweight males did not have increased risk for hypovitaminosis D (AOR 1.06, 95\% CI 0.85, 1.23) in comparison to the normal BMI males.

In our study population, the incidence of hypocalcemia in subjects with hypovitaminosis D was significantly greater than that in subjects with optimal vitamin D status. The mean concentration 
of corrected total serum calcium levels in subjects with hypovitaminosis D was also significantly lower than that in subjects with optimal vitamin D status. Serum calcium levels are regulated by homeostatic mechanisms involving calcium-sensing receptor, vitamin D and parathyroid hormone. Calcium is absorbed through both transcellular and paracellular pathways across the tight junctions. 1,25-dihydroxyvitamin D can promote paracellular calcium diffusion via up-regulation of tight junction proteins (claudin-2 and -12) in enterocytes through vitamin D receptors [43]. However, intestinal absorption of calcium increases as $25(\mathrm{OH}) \mathrm{D}$ rises up but without further increase in calcium absorption above 25(OH)D of 30-32 ng/mL [44]. Intriguingly, the adjusted AUC for hypocalcemia to predict the incidence of hypovitaminosis $\mathrm{D}$ was 0.57 indicating no discrimination in the present study. Thus far, the correlation between serum $25(\mathrm{OH}) \mathrm{D}$ and corrected total serum calcium was not conclusive. In the elderly, a significant negative correlation between serum $25(\mathrm{OH}) \mathrm{D}$ and corrected serum calcium was found [45]. Conversely, there was no significant correlation between serum 25(OH)D and corrected total serum calciumin some reports [46,47]. Besides hypovitaminosis D, causes of hypocalcemia include hypoparathyroidism [48], intestinal malabsorption, magnesium depletion [49] and hyperphosphatemia [30]. High prevalence of hyperphosphatemia in the present study may be a result of the subjects to receive a phosphorus-containing laxative as the preparation for a colonoscopy. During acute hyperphosphatemia, phosphate can bind calcium avidly to cause acute hypocalcemia. Hypocalcemia is common in chronic renal failure because of reduced renal synthesis of 1,25-dihydroxyvitamin D. However, only two patients had eGFR $<30$ in this study population. Taken together, total serum calcium levels may not reflect serum vitamin D status. Assumptions about vitamin D status should not be made based on calcium levels. 25(OH)D survey should be requested when hypovitaminosis $\mathrm{D}$ is clinically suspected. Thus, there is a need to develop a rapid, reliable, fully automated diagnostic laboratory testing and cost saving assay for 25(OH)D [50].

This study had some limitations. First, the findings were only from a single tertiary care center. However, the hospital provides community care and social service for a population $>1.3$ million that constituted a large database for the current study. Moreover, we used random sampling technique and paralleled key variables including age, gender and seasons (months) to minimize selection bias. Second, data of vitamin D intake, sun exposure behaviors, drugs such as steroids and physical activity, which are factors known to affect serum $25(\mathrm{OH}) \mathrm{D}$ concentration $[6,40]$, were not available in the present retrospective study. Nonetheless, few studies focused on the vitamin D status of indoor office workers in a subtropical Asian region-the strength of the present study. Third, ethnicity has been found to be a predictor of $25(\mathrm{OH}) \mathrm{D}$ levels $[6,15]$. Because only Taiwanese were included in the present study, the findings may not be extrapolated to other ethnic groups. Therefore, further large-scale prospective studies are warranted to determine the relative contributions of environmental factors, behavior differences, and total intake to changes in serum 25(OH)D concentrations of indoor workers living in a subtropical region.

\section{Conclusions}

In conclusion, there was a high prevalence of hypovitaminosis D among indoor office workers in a subtropical region. Younger age, female gender and season (winter/spring) were found to be predictors of hypovitaminosis $\mathrm{D}$ in the study population, whereas body-mass index was not a significant factor. The findings underscored the importance of this occupational health issue in subtropical regions. There is, therefore, a need to develop strategies to maintain adequate vitamin D status in indoor workers even in a subtropical region. Future research may include case-control studies comparing the vitamin $\mathrm{D}$ status in indoor workers with that in outdoor workers. Despite higher incidence of hypovitaminosis $\mathrm{D}$ in indoor workers with hypocalcemia, there was no definite association between vitamin $\mathrm{D}$ status and calcium levels in the present study. Assumptions about vitamin D status should not be made based on calcium levels. 25(OH)D survey should be requested when hypovitaminosis D is clinically suspected. Further studies are needed to investigate the association between vitamin $\mathrm{D}$ status and calcium levels. Prospective studies are necessary to exact more strong conclusions on these findings. 
Author Contributions: Conceptualization, L.-K.W., K.-C.H., Y.-T.L., Y.-J.C., Z.-F.W., C.-H.H. and J.-Y.C.; methodology, L.-K.W., K.-C.H., Y.-T.L., Y.-J.C., Z.-F.W., C.-H.H. and J.-Y.C.; software, K.-C.H., C.-H.H.; validation, L.-K.W., K.-C.H., Y.-T.L. and J.-Y.C.; formal analysis, C.-H.H.; investigation, L.-K.W., J.-Y.C.; resources, J.-Y.C.; data curation, J.-Y.C.; writing-original draft preparation, L.-K.W., K.-C.H., J.-Y.C.; writing-review and editing, L.-K.W., K.-C.H., Y.-T.L., Y.-J.C., Z.-F.W., C.-H.H. and J.-Y.C.; visualization, C.-H.H.; supervision, J.-Y.C.; project administration, J.-Y.C.; funding acquisition, J.-Y.C. All authors have read and agreed to the published version of the manuscript.

Funding: CMFJ10406 (Chi Mei Medical Center, Tainan, Taiwan). The funders had no role in study design, data collection and analysis, decision to publish, or preparation of the manuscript.

Conflicts of Interest: The authors declare no conflict of interest.

Data Availability: Anonymized data not published within this article will be made available and shared by request from any qualified investigator.

$\begin{array}{ll}\text { Abbreviations } \\ \text { AUC } & \text { Area under the receiver operating characteristic curve } \\ \text { 25(OH)D } & \text { 25-hydroxyvitamin D } \\ \text { BMI } & \text { Body mass index } \\ \text { ELISA } & \text { Enzyme linked immunosorbent assay } \\ \text { ICD-9 } & \text { International Classification of Diseases, Ninth Revision, Clinical Modification } \\ \text { ROC } & \text { Curve a receiver operating characteristic curve }\end{array}$

\section{References}

1. Yang, C.Y.; Leung, P.S.; Adamopoulos, I.E.; Gershwin, M.E. The implication of vitamin D and autoimmunity: A comprehensive review. Clin. Rev. Allergy Immunol. 2013, 45, 217-226. [CrossRef]

2. Feng, R.; Li, Y.; Li, G.; Li, Z.; Zhang, Y.; Li, Q.; Sun, C. Lower serum $25(\mathrm{OH})$ D concentrations in type 1 diabetes: A meta-analysis. Diabetes Res. Clin. Pract. 2015, 108, e71-e75. [CrossRef] [PubMed]

3. Ju, S.Y.; Jeong, H.S.; Kim, D.H. Blood vitamin D status and metabolic syndrome in the general adult population: A dose-response meta-analysis. J. Clin. Endocrinol. Metab. 2014, 99, 1053-1063. [CrossRef] [PubMed]

4. Soderstrom, L.H.; Johnson, S.P.; Diaz, V.A.; Mainous, A.G., 3rd. Association between vitamin D and diabetic neuropathy in a nationally representative sample: Results from 2001-2004 NHANES. Diabet. Med. 2012, 29, 50-55. [CrossRef] [PubMed]

5. Chen, J.Y.; Lin, Y.T.; Wang, L.K.; Hung, K.C.; Lan, K.M.; Ho, C.H.; Chang, C.Y. Hypovitaminosis din postherpetic neuralgia-high prevalence and inverse association with pain: A retrospective study. Nutrients 2019, 11, 2787. [CrossRef] [PubMed]

6. Holick, M.F. Vitamin D deficiency. N. Engl. J. Med. 2007, 357, 266-281. [CrossRef] [PubMed]

7. Cashman, K.D.; van den Heuvel, E.G.; Schoemaker, R.J.; Preveraud, D.P.; Macdonald, H.M.; Arcot, J. 25-hydroxyvitamin D as a biomarker of vitamin D status and its modeling to inform strategies for prevention of vitamin D deficiency within the population. Adv. Nutr. 2017, 8, 947-957. [CrossRef]

8. Holick, M.F.; Binkley, N.C.; Bischoff-Ferrari, H.A.; Gordon, C.M.; Hanley, D.A.; Heaney, R.P.; Murad, M.H.; Weaver, C.M. Evaluation, treatment, and prevention of vitamin D deficiency: An Endocrine Society clinical practice guideline. J. Clin. Endocrinol. Metab. 2011, 96, 1911-1930. [CrossRef]

9. Vu, L.H.; Whiteman, D.C.; van der Pols, J.C.; Kimlin, M.G.; Neale, R.E. Serum vitamin D levels in office workers in a subtropical climate. Photochem. Photobiol. 2011, 87, 714-720. [CrossRef]

10. Song, H.R.; Kweon, S.S.; Choi, J.S.; Rhee, J.A.; Lee, Y.H.; Nam, H.S.; Jeong, S.K.; Park, K.S.; Ryu, S.Y.; Choi, S.W.; et al. High prevalence of vitamin D deficiency in adults aged 50 years and older in Gwangju, Korea: The Dong-gu study. J. Korean Med. Sci. 2014, 29, 149-152. [CrossRef]

11. Kung, A.W.; Lee, K.K. Knowledge of vitamin D and perceptions and attitudes toward sunlight among Chinese middle-aged and elderly women: A population survey in Hong Kong. BMC Public Health 2006, 6, 226. [CrossRef] [PubMed]

12. Mithal, A.; Wahl, D.A.; Bonjour, J.P.; Burckhardt, P.; Dawson-Hughes, B.; Eisman, J.A.; El-Hajj Fuleihan, G.; Josse, R.G.; Lips, P.; Morales-Torres, J. Global vitamin D status and determinants of hypovitaminosis D. Osteoporos. Int. 2009, 20, 1807-1820. [CrossRef] [PubMed] 
13. Lee, M.S.; Li, H.L.; Hung, T.H.; Chang, H.Y.; Yang, F.L.; Wahlqvist, M.L. Vitamin D intake and its food sources in Taiwanese. Asia Pac. J. Clin. Nutr. 2008, 17, 397-407. [PubMed]

14. Ginde, A.A.; Liu, M.C.; Camargo, C.A., Jr. Demographic differences and trends of vitamin D insufficiency in the US population, 1988-2004. Arch. Intern. Med. 2009, 169, 626-632. [CrossRef] [PubMed]

15. Man, R.E.; Li, L.J.; Cheng, C.Y.; Wong, T.Y.; Lamoureux, E.; Sabanayagam, C. Prevalence and determinants of suboptimal vitamin D levels in a multiethnic Asian population. Nutrients 2017, 9, 313. [CrossRef]

16. Lagunova, Z.; Porojnicu, A.C.; Lindberg, F.; Hexeberg, S.; Moan, J. The dependency of vitamin D status on body mass index, gender, age and season. Anticancer Res. 2009, 29, 3713-3720. [CrossRef]

17. OliaiAraghi, S.; van Dijk, S.C.; Ham, A.C.; Brouwer-Brolsma, E.M.; Enneman, A.W.; Sohl, E.; Swart, K.M.; van der Zwaluw, N.L.; van Wijngaarden, J.P.; Dhonukshe-Rutten, R.A.; et al. BMI and body fat mass is inversely associated with vitamin D levels in older individuals. J. Nutr. Health Aging 2015, 19, 980-985. [CrossRef]

18. Wanner, M.; Richard, A.; Martin, B.; Linseisen, J.; Rohrmann, S. Associations between objective and self-reported physical activity and vitamin D serum levels in the US population. Cancer Causes Control 2015, 26, 881-891. [CrossRef]

19. Coppeta, L.; Papa, F.; Magrini, A. Are shiftwork and indoor work related to D3 vitamin deficiency? A systematic review of current evidences. J. Environ. Public Health 2018, 2018, 8468742. [CrossRef]

20. Choi, E.Y. 25(OH)D status and demographic and lifestyle determinants of 25(OH)D among Korean adults. Asia Pac. J. Clin. Nutr. 2012, 21, 526-535.

21. Huang, C.H.; Huang, Y.A.; Lai, Y.C.; Sun, C.K. Prevalence and predictors of hypovitaminosis D among the elderly in subtropical region. PLoS ONE 2017, 12, e0181063. [CrossRef] [PubMed]

22. Schleicher, R.L.; Sternberg, M.R.; Looker, A.C.; Yetley, E.A.; Lacher, D.A.; Sempos, C.T.; Taylor, C.L.; Durazo-Arvizu, R.A.; Maw, K.L.; Chaudhary-Webb, M.; et al. National estimates of serum total 25-hydroxyvitamin D and metabolite concentrations measured by liquid chromatography-tandem mass spectrometry in the US population during 2007-2010. J. Nutr. 2016, 146, 1051-1061. [CrossRef] [PubMed]

23. Yeh, C.J.; Chang, H.Y.; Pan, W.H. Time trend of obesity, the metabolic syndrome and related dietary pattern in Taiwan: From NAHSIT 1993-1996 to NAHSIT 2005-2008. Asia Pac. J. Clin. Nutr. 2011, 20, 292-300. [PubMed]

24. Mansueto, P.; Seidita, A.; Vitale, G.; Gangemi, S.; Iaria, C.; Cascio, A. Vitamin D deficienczy in HIV infection: Not only a bone disorder. Biomed. Res. Int. 2015, 2015, 735615. [CrossRef]

25. Stein, E.M.; Shane, E. Vitamin D in organ transplantation. Osteoporos. Int. 2011, 22, 2107-2118. [CrossRef]

26. Lee, M.J.; Hsu, H.J.; Wu, I.W.; Sun, C.Y.; Ting, M.K.; Lee, C.C. Vitamin D deficiency in northern Taiwan: A community-based cohort study. BMC Public Health 2019, 19, 337. [CrossRef]

27. Levis, S.; Gomez, A.; Jimenez, C.; Veras, L.; Ma, F.; Lai, S.; Hollis, B.; Roos, B.A. Vitamin D deficiency and seasonal variation in an adult South Florida population. J. Clin. Endocrinol. Metab. 2005, 90, 1557-1562. [CrossRef]

28. Floege, J.; Tsirtsonis, K.; Iles, J.; Drueke, T.B.; Chertow, G.M.; Parfrey, P. Incidence, predictors and therapeutic consequences of hypocalcemia in patients treated with cinacalcet in the EVOLVE trial. Kidney Int. 2018, 93, 1475-1482. [CrossRef]

29. Bushinsky, D.A.; Monk, R.D. Electrolyte quintet: Calcium. Lancet 1998, 352, 306-311. [CrossRef]

30. Gutierrez, O.; Isakova, T.; Rhee, E.; Shah, A.; Holmes, J.; Collerone, G.; Juppner, H.; Wolf, M. Fibroblast growth factor-23 mitigates hyperphosphatemia but accentuates calcitriol deficiency in chronic kidney disease. J. Am. Soc. Nephrol. 2005, 16, 2205-2215. [CrossRef]

31. Creswell, J.W. Research Design: Qualitative, Quantitative and Mixed Methods Approaches; Sage: London, UK, 2004; Volume 12, pp. 82-83. [CrossRef]

32. Koivula, M.K.; Matinlassi, N.; Laitinen, P.; Risteli, J. Four automated 25-OH total vitamin D immunoassays and commercial liquid chromatography tandem-mass spectrometry in Finnish population. Clin. Lab. 2013, 59, 397-405. [CrossRef] [PubMed]

33. Janssen, J.W.; Helbing, A.R. ArsenazoIII: An improvement of the routine calcium determination in serum. Eur. J. Clin. Chem. Clin. Biochem. 1991, 29, 197-201. [PubMed]

34. Gamst, O.; Try, K. Determination of serum-phosphate without deproteinization by ultraviolet spectrophotometry of the phosphomolybdic acid complex. Scand. J. Clin. Lab. Investig. 1980, 40, 483-486. [CrossRef] [PubMed] 
35. Garcia Moreira, V.; BeridzeVaktangova, N.; Martinez Gago, M.D.; Laborda Gonzalez, B.; Garcia Alonso, S.; Fernandez Rodriguez, E. Overestimation of albumin measured by bromocresol green vs bromocresol purple method: Influence of acute-phase globulins. Lab. Med. 2018, 49, 355-361. [CrossRef]

36. Choi, H.S.; Oh, H.J.; Choi, H.; Choi, W.H.; Kim, J.G.; Kim, K.M.; Kim, K.J.; Rhee, Y.; Lim, S.K. Vitamin D insufficiency in Korea-A greater threat to younger generation: The Korea National Health And Nutrition Examination Survey (KNHANES) 2008. J. Clin. Endocrinol. Metab. 2011, 96, 643-651. [CrossRef]

37. Chailurkit, L.O.; Aekplakorn, W.; Ongphiphadhanakul, B. Regional variation and determinants of vitamin D status in sunshine-abundant Thailand. BMC Public Health 2011, 11, 853. [CrossRef]

38. Nimitphong, H.; Holick, M.F. Vitamin D status and sun exposure in Southeast Asia. Dermatoendocrinology 2013, 5, 34-37. [CrossRef]

39. MacLaughlin, J.; Holick, M.F. Aging decreases the capacity of human skin to produce vitamin D3. J. Clin. Investig. 1985, 76, 1536-1538. [CrossRef]

40. Malacova, E.; Cheang, P.R.; Dunlop, E.; Sherriff, J.L.; Lucas, R.M.; Daly, R.M.; Nowson, C.A.; Black, L.J. Prevalence and predictors of vitamin D deficiency in a nationally representative sample of adults participating in the 2011-2013 Australian Health Survey. Br. J. Nutr. 2019, 121, 894-904. [CrossRef]

41. Hayashi, F.; Takimoto, H.; Yoshita, K.; Yoshiike, N. Perceived body size and desire for thinness of young Japanese women: A population-based survey. Br. J. Nutr. 2006, 96, 1154-1162. [CrossRef]

42. Okabe, H.; Shimizu, C.; Yamamoto, M.; Kikuchi, R.; Minami, A.; Chen, Y.F.; Imai, H.; Mizuta, M.; Chen, Z.; Chiba, H.; et al. Determination of serum 25-hydroxyvitamin D3 by LC/MS/MS and its monthly variation in sapporo indoor workers. Anal. Sci. 2018, 34, 1043-1047. [CrossRef] [PubMed]

43. Fujita, H.; Sugimoto, K.; Inatomi, S.; Maeda, T.; Osanai, M.; Uchiyama, Y.; Yamamoto, Y.; Wada, T.; Kojima, T.; Yokozaki, H.; et al. Tight junction proteins claudin-2 and -12 are critical for vitamin D-dependent Ca2+ absorption between enterocytes. Mol. Biol. Cell 2008, 19, 1912-1921. [CrossRef] [PubMed]

44. Heaney, R.P. Vitamin D and calcium interactions: Functional outcomes. Am. J. Clin. Nutr. 2008, 88, 541S-544S. [CrossRef]

45. Lamberg-Allardt, C. The relationship between serum 25-hydroxy-vitamin D levels and other variables related to calcium and phosphorus metabolism in the elderly. ActaEndocrinol. (Copenhagen) 1984, 105, 139-144. [CrossRef] [PubMed]

46. Timalsina, S.; Sigdel, M.R.; Baniya, S.; Subedee, S. Status of vitamin D and parameters of calcium homeostasis in renal transplant recipients in Nepal: A cross sectional study. BMC Nephrol. 2018, 19, 290. [CrossRef]

47. Haarburger, D.; Hoffman, M.; Erasmus, R.T.; Pillay, T.S. Relationship between vitamin D, calcium and parathyroid hormone in Cape Town. J. Clin. Pathol. 2009, 62, 567-569. [CrossRef] [PubMed]

48. Wang, Y.H.; Bhandari, A.; Yang, F.; Zhang, W.; Xue, L.J.; Liu, H.G.; Zhang, X.H.; Chen, C.Z. Risk factors for hypocalcemia and hypoparathyroidism following thyroidectomy: A retrospective Chinese population study. Cancer Manag. Res. 2017, 9, 627-635. [CrossRef]

49. Rude, R.K. Renal cortical adenylate cyclase: Characterization of magnesium activation. Endocrinology 1983, 113, 1348-1355. [CrossRef]

50. Hutchinson, K.; Healy, M.; Crowley, V.; Louw, M.; Rochev, Y. Verification of Abbott 25-OH-vitamin D assay on the architect system. Pract. Lab. Med. 2017, 7, 27-35. [CrossRef]

(C) 2020 by the authors. Licensee MDPI, Basel, Switzerland. This article is an open access article distributed under the terms and conditions of the Creative Commons Attribution (CC BY) license (http://creativecommons.org/licenses/by/4.0/). 